\title{
Adult education and school programs: The two co- funded ABC Educational TV Services
}

\author{
Grahame Ramsay \\ University of Western Sydney, Nepean
}

\begin{abstract}
The traditional role of the $\mathrm{ABC}$ in supporting education has become more complicated under new funding arrangements to support programs for schools and to introduce adult education. Various options and directions for childrens' and adult education have been debated for some time in the $\mathrm{ABC}$ but the present solution incorporates some fascinating elements that had not been foreseen. It has been clear, since 1990, that there was a funding short-fall that would place the future of $A B C$ school broadcasts at risk but the solution adopted is both novel and effective. This article considers how the two education services have come about in the ABC. It ponders how they have gained support in a period of reduced Federal government funding for the $\mathrm{ABC}$ when the future of educational broadcasting looked bleak. It also examines how some of the long debated issues, of the role of the $\mathrm{ABC}$ as a provider of national educational resources, have been resolved.
\end{abstract}

Educational television has been part of the way the ABC defined itself as a public service broadcaster. Yet as Tracey (1990: 1) has observed:

National broadcasting systems are everywhere being forced to re-examine their purpose, nature and mission. The past decade has seen a widespread assault on the importance, even legitimacy of public service broadcasting in the major democracies.

This paper will consider how the "assault on the legitimacy" of educational television occurred within the $\mathrm{ABC}$. It will examine the remarkable 
funding arrangements that have ensured the service for schools continues, and allowed for the introduction of adult education under the rubric of Open Learning.

In the case of school broadcasts the $A B C$ is currently broadcasting programs of three general types: original Australian, Australian repeats and new overseas purchases. There is the Australian produced flagship, Behind the News, the most popular program specifically made for schools (Palmer \& Black, 1987). It is paid for out of the budget of the ABC Childrens Department to the tune of about one million dollars (in total costing terms) per annum. Then, there are 80 hours per year of repeat programs that were produced by $A B C$ staff in previous years. Next, the new material, some 70 hours of overseas programs purchased out of money paid to the $\mathrm{ABC}$. This money is paid, under the Copyright Amendment Act 1989, by the school education departments. The arrangement has been a bonus for the education section of the $A B C$. Money collected by the Audio Visual Copyright Society, under the Act, from state education departments goes to the $A B C$ and is used to purchase programs from overseas.

This money is paid by state school education departments to compensate copyright owners for recordings made off air by schools. The total pool for the 1990/1991 financial year was some 1.2 million dollars, a proportion of which was allocated to the $\mathrm{ABC}$.

The $\mathrm{ABC}$ has also moved into an area of adult education as part of a consortium including five universities to develop the $\$ 1$ million dollar Open Learning Project. Under the pilot scheme, which began in 1992, adult education television series are being screened on early morning timeslots by the $\mathrm{ABC}$. Written course materials and examinations are being coordinated by the Universities. Both these arrangements bear closer examination in the light of the historical partnership between educators and the $\mathrm{ABC}$.

\section{Issues for educational program production}

Information from UNESCO suggests that explicitly educational materials amount to 10 percent of all television programming as a world average. Such materials fall roughly into four sub-categories: pre-school, in-school, home study, and adult education (Hood, 1983). The ABC broadcasts preschool (Playschool, Sesame street), in-school (ABC Daytime) and now home study and adult education (Open Learning).

Educational program making involves broadcasters in complex partnerships between the values of education and the values of television production. At the simple level a person producing education programs must have some understanding of educational principles as well as the 
techniques of production. There are also important differences in the way a program is designed for its audience in educational television (Groundwater-Smith, 1990).

New forms of programs are also being developed that take account of video off air recording which are designed from the outset to give the learners greater opportunity to control and interact with the material (Kirkwood 1988: 77).

This paper will identify some of the key issues that have concerned educational television program makers over the last decade. They include consideration of whether educational programs are a "genre" separate from other kinds of program making; issues of who should make educational programs; the relationship between audience, client and producer; copyright issues and the evaluation educational programs.

\section{The Development of Adult Education Programs}

One of the implicit roles of a public service broadcaster has been to provide news, current affairs and documentary programs which could be broadly characterised as being "educative". Indeed the ABC repeats many such programs during daytime slots as part of its education service. In 1992 this includes: Four Corners, Media Watch, Quantum, Investigators, Compass, Couchman, and Landline. However worthwhile and educative these programs may be, they do not fulfil some important adult education needs such as literacy, numeracy, job seeking skills, languages and computer literacy. Adult Education, by television, is a term that requires definition. The European Broadcasting Union states that in the broadcasting context the term refers to programs "which aim to give adults progressive comprehension of a body of knowledge, or help them acquire skills in a defined field, or equip them better for participation in community life" (cited in Perlgut, 1989, 1).

In the last decade debates about Adult Education on $A B C$ Television frequently became stagnated when any proposals by the $\mathrm{ABC}$ Education Department to provide programs in that area were going to be at the expense of the service for schools (Ramsey 1988a). The development of adult education, for television, had been proposed actively by $A B C$ education producers since 1980 but had always been seen to pose a threat to the schools service. Any expansion into adult education would take a large slice out of the already small cake of funds available to produce programs for the schools audience. It never really developed comprehensively within the ABC until 1986 when the Learning Network Pty Ltd, an outside commercial company, suggested using the ABC's early morning time-slots to deliver "telecourse" material. Their project was for the $\mathrm{ABC}$ (and SBS) to broadcast adult learning materials, and for individuals and educational institutions to pay a licence fee to record and 
use those materials. The first telecasts were in March 1987 and aimed to demonstrate a range of different course areas. These included management development, computer literacy, marketing, basic electronics and health education. The material was $80 \%$ from overseas. It also included some telecourses produced in Australia specifically for health education. Despite initial promise the project faltered under political, promotional and financial difficulties. By the end of 1988 Learning Network Pty Ltd had run out of funds to continue and the company has since reverted to the role of program supplier. Ten factors were identified in the final evaluation report of the Learning network's performance (Widdowson, 1990:165). These can be summarised as:

- under-funding,

- under ahead of its time in Australia,

- under State/Federal politics,

- under lack of Australian produced material,

- under public sector resentment to a private sector initiative,

- under competitive services in Victoria,

- under restructuring of the Federal training and education department,

- under lack of a dedicated TV studio,

- under competition from educational institutions with their own TV production facilities, and

- under and Federal budget cuts to the states.

The ABC did not lose faith in the area of Adult Education and advertised for a person in 1989 to develop and promote the area. The successful applicant, Don Perlgut, produced a guide to present $A B C$ programs and resources that were useful for the education of adults. He was also involved in developing the adult literacy program Fresh Start which was broadcast in 1990 (Perlgut, 1991).

\section{Open Learning}

Open Learning is an initiative of the federal Department of Education and Training. In a media release $(1 / 2 / 91)$, the federal Minister for Higher Education, Mr P. Baldwin, described Open Learning as "a method of improving access to higher education". He said that the one million dollar pilot project would use television to augment existing distance education materials. The aim of the project was to extend access to people who are not able to attend on campus courses because of work or family commitments, disability or because they live in isolated areas. The concept of open learning has been adopted by a number of countries including the United Kingdom, Canada and Hong Kong, and, according to the Minister, there were a number of open learning initiatives underway in Australia. The Minister said that the pilot project would be conducted on a small scale and would be used to gauge the potential of educational television to 
improve access to higher education and promote open learning. The Minister also indicated that there was considerable potential for the open learning project to be expanded in future years on a cost recovery basis. The Minister also said that DEET was "examining the general issue of the potential of television broadcasting to contribute to post secondary school education and training".

In a separate document (DEET, 1991) the "Open Learning Project" was outlined to organisations who might want to tender for the one million dollars. The project was described as extending access to first year degree courses through the use of educational television and independent learning materials. It was to give access to those who may not be able to attend University for reasons of isolation or circumstance The project was also intended to provide a "taste" of higher education, through the television programs, to those in the community who would not normally consider enrolling in a higher education institution. DEET invited universities, in cooperation with broadcasters, to tender for the one million dollars offered for the pilot project. The successful tender were a consortium of five universities led by Monash University with the ABC as the host broadcaster. The project is largely funded from the DEET money with some donation of facilities and archival material by the ABC (1). The cost of printed course materials is fully borne by those students who purchase them. People who have bought course materials are also entitled to sit for examinations and if successful they will have equivalent credit for each subject completed towards an appropriate degree in the future.

The five universities are Monash (Marketing), University of New England (French), Griffith (Images of Australia), University of South Australia (Religious Studies) and Deakin University (Statistics).

There are also some cross-crediting arrangements with other universities. For example, Macquarie University (who are not part of the consortium) has produced a guide for its own students about how the Open Learning subjects may count towards a Macquarie degree.

The response to the project has been much greater than expected with some 4,000 students requesting written subject material (2). The latest figures are:

\begin{tabular}{lll} 
Subject & Provider & Students \\
\hline French & UNE & 1,914 \\
Marketing & Monash & 702 \\
Images of Australia & Griffith & 440 \\
Religious Studies & Uni of Sth Australia & 397 \\
Statistics & Deakin & 309
\end{tabular}


There are no entry requirements and the ability to pay for the subject materials (about \$200) and watch the program on a television set are the only requirements. Registration for assessment costs about $\$ 200$ per subject. The youngest student is a 14 year old doing French and the oldest is a ninety year old.

The Minister for Higher Education said recently that the government was considering a proposal from Queensland University and Monash University to expand the television Open Learning project. This is a response to the record shortfall of university places by nearly 50,000 for 1992 and a perception that Open Learning may provide part of a solution to unmet demand (3).

\section{The Development of School Education Broadcasts}

The $\mathrm{ABC}$ has acted as both a producer and distributor of education television programs for the past 33 years.

In 1986, for example, it provided some 800 hours of programs for primary and secondary schools. $\mathrm{ABC}$ staff in each state produced programs to contribute to the national schedule with an overall total of 75 hours of first release Australian material produced in 1986/1987 financial year(4). In 1992 the .figure has dropped to 150 hours per annum comprising 70 hours of new programs and 80 hours of repeat programs for schools. The ABC has stopped producing programs for schools "in-house" except for the very popular Behind the News program which the Head of Childrens' TV says would be funded and screened even if no other educational programs were broadcast. The decision to buy overseas rather than produce local material is described as getting the best value for the limited amount of money available. Overseas series are cheaper to buy than for the ABC to produce an Australian equivalent (5).

The ABC's complex partnership with educators and support for educational broadcasting mirrors many of the issues of the partnership of other technologies and education. There are now a much greater range of information technologies that can be used in education. As a recent review of learning technologies indicates television is but one of many technologies that may be applied to education and a group of senior state education officials are currently considering how best to spend their limited money on using educational technology, with assisting the $A B C$ as only one of many options(6). "The major trends towards integration of technologies and in the way ideas are manipulated, sorted, shared and communicated, raises challenges for education and training" (Hedberg, 1989: 156).

The focus of this paper is on the production end of educational television and the complex interactions within the $\mathrm{ABC}$ and between the $\mathrm{ABC}$ and the educational bureaucracy. It is acknowledged that this is only half the 
story and that the reception end, the learners response to the programs be they children or adults - is also critically important. Educational programs are "texts" to which many meanings can be given, and the learner is by no means a passive receiver (Groundwater-Smith, 1990). Research also indicates that children use television quite differently from adults (Palmer 1986).

The persistence of the $\mathrm{ABC}$ in broadcasting educational programs for three decades indicates a belief in the place of education in public service broadcasting. There are institutional 'meanings' at the production end of educational programs that need to be investigated.

\section{The genre dilemma}

Just what "genre" an educational program belongs to has presented some challenges for program producers and audiences alike. Unlike other television programs which can be defined by "genre", education programs, both for children and adults, are defined more by purpose than by recognisable form.

This purpose has shifted, in the $\mathrm{ABC}$, from teacher replacement programs of the 1960s to the enrichment programs of the 1990s.

Early programs included teachers presenting "model" lessons, but within two years this had given way to programs that were more documentary in style and designed for enrichment. (FEBAC Minutes 1964). By the 1980s the genres of broadcast television were used but with an educational purpose.

Within a broadcasting organisation programs are also defined in relation to the other output of the organisation. It is only in the last 5 years with the launch of $\mathrm{ABC}$ Daytime that the Education programs have been packaged in a style similar to the rest of the output of $A B C$ Television. Before then the prevalence of clocks and test pattern between programs created the image of the $A B C$ as a distributor of resources for schools rather than a broadcaster with a continuous flow of material during the day.

Education programs have also been limited by the kind of budgets allocated to them. A drama style might be the best way to present a program but if the budget only allows for documentary shooting then that was the genre chosen. The Dix Committee observed, in 1981, that Education programs received lower budgets proportionately than equivalent programs produced by other departments within $\mathrm{ABC}$ Television $(1981,16)$.

There is evidence that budget reductions for particular areas were a reflection of the opinions of senior staff about the merits of certain areas and programs of the ABC. The Education Department has been a victim of 
what has been called "the enemy within" (Peach, 1992). The ABC Board were also quick to point out the apparent anomaly of a national (federal) broadcaster providing programs on behalf of education departments which were a state responsibility (Molomby, 1991).

There is also evidence of long-standing belief that the Education section of the $A B C$ should not be allowed to expand if this was to be at the expense of other programs in the $\mathrm{ABC}$.

As the Chairman of the ABC put it in 1967, the ABC had to continue to accept its responsibility to the whole community to provide a balanced schedule and could not divert too great a proportion of its facilities and resources to education alone (FEBAC Minutes 1967).

Despite these drawbacks the $\mathrm{ABC}$ still represents the most viable way of broadcasting to a potential $98 \%$ of the Australian population and to homes and schools equipped with at least one television. The scarce pool of funds for the broadcaster with persistent cuts by federal governments have led to enormous budget constraints and contraction for the Education Department of the ABC. However, the broadcast connection has allowed for a maintenance of "broadcast standard" in lighting, presentation and script writing for those education programs that are still being screened by the $\mathrm{ABC}$ : standards that the state education departments have found difficult to match with their own small video units. This issue of the importance of "broadcast standard" was to prove a key determination in the style of the Open Learning programs telecast by the ABC in 1992.

\section{The impact of changes in $A B C$ departmental structures}

The major changes in the structure of the $\mathrm{ABC}$ in the 1980s shifted the ABC Education Department both philosophically and practically. It changed from a Department with production centres in each state to a centralised Childrens' and Education Department with more hybrid responsibilities for the education and entertainment of children.

In the transition to the new Childrens' and Education Department many of the links with the school education departments were severed. The state school education departments were also under-going their own restructuring and withdrew support for seconded liaison officers to the $\mathrm{ABC}$, thus further reducing on-going consultation between the departments and the $\mathrm{ABC}$.

The use of a satellite to transmit $A B C$ programs nationally also had a major impact on school broadcasts. In 1987 state-based scheduling of school broadcasts was replaced by a unified national schedule. In the past programs specific to curriculum developments in one state had been telecast: now the whole of Australia received the same programming. As a 
response to this, SBS, in cooperation with the state systems, developed TV Ed which is still broadcasting material thirty minutes per day, much of it with a very specific state focus. NSW, for example, are responsible for the Monday afternoon program from $4.00-4.30 \mathrm{pm}$. There is a greater emphasis on staff development for teachers in these programs.

The $\mathrm{ABC}$ structure of education production centres in each state was changed, removing that link to state-based education. The Perth production team closed up in December 1988, the Brisbane team in June 1989 and the Hobart team in December 1989.

By 1990 the CHED department of the ABC had only three production centres: in Sydney, Melbourne and Adelaide. In October 1990 a new job was advertised for a Head, Childrens' Television. The job was described as being responsible for the $A B C$ 's day-time programming of childrens' television. The person would be "required to oversee in-house production, select programs for purchase and schedule programs". The new department was to be called simply Childrens' Television.

\section{Copyright}

The current situation under the Copyright Amendment Act (1989) is that it is now possible for schools and other institutions to make copies of any television program for educational purposes. There is a requirement that "equitable remuneration" be paid to the copyright owner and that there be compliance with the scheme for copying agreed with the Audio Visual Copyright Society.

The resolution of the copyright issue has provided an unexpected source of funding for $\mathrm{ABC}$ school broadcasts. The state school departments, the universities, TAFE and independent schools have all entered into agreements to pay for use of programs. The $A B C$ is entitled to a proportion of the money collected based on a survey of what programs are being recorded. The exact amount the $\mathrm{ABC}$ receives is confidential but it is sufficient to fund the purchase of 70 hours of new programs. The new programs purchased are all from overseas. An agreement has been reached with the copyright owners of these overseas programs to contract their AVCS entitlement to the ABC so that the AVCS money that will accrue from those programs goes to the $\mathrm{ABC}$. Consequentially the scheme provides an incentive for the $\mathrm{ABC}$ to continue to purchase programs and is self-funding.

The money raised in the first year was at the rate of 60 cents per child in Australian schools with an estimated 3 million children covered nationally by the scheme. This includes the government, private and catholic schools. The amount of money actually available for distribution to all copyright owners in the financial year ended 30 June 1991 was 1.2 million dollars (2). 
The ABC would have received a proportion of this which has been used to purchase overseas education programs. The rate for this financial year is 70 cents per child which is likely to raise about 2.1 million dollars. A further large pool of that money will automatically go to the $A B C$ as "copyright owners" of the material broadcast.

Copyright has caused more anxiety for teachers and producers than any other issue in educational broadcasting. The previous Copyright Act (1968) prohibited any copying of television programs for schools. There was a provision relating to education radio programs but not television. Schools that made copies of ABC school broadcasts between 1968 and July 1990 were breaking the law. Schools and teachers could have been prosecuted. There were no major prosecutions because of an informal arrangement with the Attorney General's Department that no prosecutions should be launched. There is still some ignorance of the recent changes to copyright. A senior official I spoke to in the Victorian Ministry of Education had never heard of the AVCS arrangement and believed that $\mathrm{ABC}$ programs were free of any copyright. The per child agreement has however been adopted by Victoria even if it is not widely publicised.

The arrangement with schools does not limit the number of programs recorded for educational purposes and has been a godsend for the $A B C$ schools service. By comparison, all but one university have negotiated an agreement where each off-air recording is logged and the user pays a per minute fee from their faculty budget. With low "faculty budgets" this provides a major disincentive to record programs.

The only danger for schools is if the cost of 70 cents per child is collected directly from schools on an individual basis, rather than from the education department head office as a gross figure.

While the cost at this stage is being met centrally by the NSW Department of School Education, global budgeting in schools may see this fee being added on a pro-rata basis to the expenses of individual schools.

The frequently repeated slogan that the state education systems should contribute money to fund these programs broadcast by the $\mathrm{ABC}$ has come about. It took a copyright act to do it but the users are now paying for the service.

\section{Program Evaluation: School Broadcasts}

There is good reason to ponder on how we can evaluate the effectiveness of individual education television programs. With production costs of about 100,000 dollars per hour for new material, educational television programs are an expensive resource and it is quite proper to know whether they meet their objectives. 
The first test of effectiveness is simply how many people are watching school programs. Until 1986 there were no reliable national figures. But since then there has been a systematic evaluation with three National Surveys of the Use of Television Broadcasts in Schools. These were an initiative of the former Head of Childrens and Education Television, Ms Henrietta Clark, who had the vision to realise that empirical data on audience size was one of the most persuasive means of gaining support for school programs within the $\mathrm{ABC}$. The verifiable enormous ratings for Behind the News remains the key to its continued support by the ABC. A review of Federal Education Broadcast Advisory Committee Minutes, 1967-1983, indicates that it was not until Ms Clark took over the Department that much of this important research was conducted. Before her time their had been proposals but no action. It was also her initiative to appoint a Federal Education Liaison officer and someone to coordinate Adult Education.

The data gained surpasses any previous information collected by the $A B C$ on the size of the audience for school television programs. The 1988 National survey of teachers indicated that $85 \%$ of primary schools teachers and $83 \%$ of secondary schools teachers used $\mathrm{ABC}$ schools' programs. The highest rating program was Behind the News with an estimated audience of almost one million children.

Words and Pictures followed with an audience estimated at 804,300, For the Juniors, 723,400 and Flip Slide Turn, 533,300. It is estimated that 15 series for primary schools have an audience of over 250,000.

Qualitative research on whether the programs actually achieve their objectives is more difficult. The evaluation of programs has generally been conducted informally through regional contacts and other feedback.

Susan Groundwater-Smith (1990) has adopted a "case study inquiry approach" to investigate how programs are actually used in schools. The study also examined the perceptions of the people who produced the programs.

All these qualitative research projects are expensive. One possible option for the future is to build program evaluation into the original production budget to ensure that it is actually conducted. This has happened with the Open Learning project which has funds allocated for an independent evaluation while the pilot is underway.

The commercial non-broadcast industry has already developed some criteria by which it evaluates its programs. There is also a long tradition of market research of commercial television programs and advertisements.

This includes such methods as groups of consumers all watching programs in a cinema and simultaneously rating their interest as they are viewing the program. Whether such a scheme is desirable or possible with 
schools or adult education programs is problematic. There is also a lot of research evidence on the effectiveness of public communication campaigns. Issues such as Road Safety, AIDS education Anti-Smoking and Anti-littering campaigns. This research may have some relevance to the evaluation of educational television programs that frequently embody "pro-social" objectives (Rice, 1989).

\section{Program Evaluation: Open Learning}

The independent evaluation of the TV Open Learning Project started in January 1992. The Director is Professor Bruce Keepes, Associate Professor in the Faculty of Education, University of Sydney, and his colleagues are Professor Sam Ball and Associate Professor Ken Sinclair.

There are some radical aspects of the Open Learning project compared to the highly regulated entry methods currently adopted by Universities. For Open Learning there are:

- No entry requirements

- No quotas

- Only first year subjects

- No higher education scheme fees

- Thirteen week study period with no breaks

- Self-funding in terms of course materials

- Cross credit between different agencies

The evaluation methods adopted by the research project are as follows:

- A questionnaire is sent at the time when students purchase written subject notes.

- A follow up survey is sent towards the end of the course

- A case study is being made of an Australian designed and produced program (Images of Australia: Griffith University)

- A follow up interview is carried out with some students.

The preliminary results of this study indicate that the students for the programs differ between subjects. In the case of French, most of the respondents were better educated older people, some already graduates, who were using it as a refresher course.

There have been some unexpected aspects: students in Victoria have initiated moves to set up study groups. This was not the original intention of the project which was actually designed for people who were not able to attend study groups.

The preliminary study indicates that the project does succeed in increasing access. There are, however, a number of people who were not in the target group set by DEET. This is not viewed as a concern since the user pays, so 
it doesn't matter who is using the materials. Some of the universities in the consortium have set up a help line for students which is open at certain hours, in response to the project.

\section{Future Options}

Two million dollars is proposed for the 1992/1993 financial year with seven program series under consideration.

The amount of telecourse material purchased from overseas is quite high. French and statistics videos are from overseas. Religion is based on a BBC series called the Long Search. To it was added 10 minutes of panel discussion produced by the $\mathrm{ABC}$ and also one complete Australian program looking at aboriginal religion. Images of Australia, a joint project between the $A B C$ and Griffith University, is the only fully Australian production made for the series.

Although it inevitably comes down to questions of money, there are local producers outside the $\mathrm{ABC}$ who could contribute quality material. For example Film Australia has a long-standing track record in the production of educational programs for adults. The Manager, Sales and Marketing Operations, Fiona Boyd says that Film Australia would of course like to maintain its involvement with the $\mathrm{ABC}$ by continuing to provide high quality Australian programming for the ABC's educational slots (6).

The funding arrangements have ensured the survival of the ABC's schools service in a form that allows for the purchase of new material. The DEET pilot project which may be extended further has provided a stimulus to adult education. The brief for the ABC in these areas is clear. It is one of the things that distinguishes it so clearly from commercial television that operates on quite different assumptions. There are a whole range of technological options for the future, such as pay television, narrowcasting with compressed video down telephone lines, optical fibre links, satellite networks to factories, colleges and universities. Some are already in use by state authorities such as TAFE, in aboriginal communities (Batchelor College in the Northern Territory) and in the private sector for communication with staff around Australia (Commonwealth Bank). Perhaps the most fundamental political issue to address will be the competing national perspectives and state parochialism.

The TV ED program on SBS has dealt with the different state needs by allowing programs with a parochial and specific state function to be broadcast. The $\mathrm{ABC}$ has avoided this narrowcasting approach.

There is also the Queensland Government Satellite Network, established in 1985. It consists of satellite receiving facilities at a number of major sites including TAFE colleges, state schools and other state government 
institutions throughout Queensland. The Queensland Department of Education uses the network to provide professional development programs for staff. These include interactive video tale-conferences which allow remote viewers to see studio guests and talk to them by telephone. Queensland also has a television service for remote schools which is broadcast during the day via a commercial television station, QTV.

Whatever delivery system occurs in the future will have to take account of state needs and state diversity in education.

\section{Endnotes}

(1) Interview with Mr Nick Collis-George, Head Childrens Department, ABC TV, 18/5/92.

(2) Interview with Professor Bruce Keepes 21/5/92.

(3) Report in the Australian newspaper, 20/5/92 "The Minister for Higher Education, Mr Baldwin, said that the Government was considering a proposal from Queensland University and Monash University to expand the Open Learning project".

(4) An estimate contained in an information paper prepared in September 1986 for the ABC Board. The figure takes account of the then policy to repeat programs so that the actual hours of transmission were greater.

(5) Interview with Mr Nick Collis-George, Op cite.

(6) Ibid

(7) Interview with Ms Suzie Bridge, Executive Director, Audio-visual Copyright Society. 20/5/92.

(8) Interview with Ms Fiona Boyd, Manager Sales and Marketing Operations Film Australia 22/5/92.

\section{References}

ABC Corporate Plan 1985-1988

ABC Corporate Plan 1986-1989

ABC Annual reports 1970-1990

ABC Achievement in the implementation of Dix, 1983-1985

ABC Daytime, 1987-1991

Barnett, S. \& Docherty, D. (1986). Public Service Broadcasting. Media Information Australia, 40.

Bates, T. \& Robinson, J. (eds) (1977). Evaluating Educational Television and Radio. Milton Keynes: Open University Press.

Blakely, R. (1979). Educational Broadcasting in the United States. Syracuse: Syracuse University Press.

Cunningham, S. (1989). Textual Innovation in the Australian Historical Mini-series. In Tulloch, J. \& Turner, G. (eds), Australian Television. Sydney: Allen \& Unwin

Davis, G. (1986). Deconstructing the ABC. Australian Quarterly, 58, 2. 
Department of Employment, Education and Training (1991). Open Learning Project: Outline of Proposal. Canberra: DEET.

Denshire, J. (ed) (1992). ABC Education Catalogue. Gosford: Ashton Scholastic.

Dix, A. (Chairman) (1981). The ABC in Review Vol 1-5. Canberra: Australian Government Publishing Service.

Dranov, P. et al (1980). Video in the Eighties. New York: Knowledge Industry Publications.

Federal Education Broadcast Advisory Committee. Minutes, 1967-1983.

Gilmour, C. (Chmn) (1979). The role of ABC Educational Broadcasting. Sydney: FEBAC.

Groundwater-Smith, S. (1990). Perspectives on Schools' Broadcasting. Curriculum Support Unit, NSW Department of School Education.

Hedberg, J. (1989). Rethinking the selection of learning technologies. Australian Journal of Educational Technology, 5(2), 132-160. http: / / www.ascilite.org.au / ajet/ ajet5/hedberg2.html

Inglis, K. (1983). This is the ABC. Melbourne: Melbourne University Press.

Kirkwood, J. (1988). Into the Video Age. Journal of Educational Television, 14, 213-225.

Molomby, T. (1991). Is there a Moderate on the Roof. Melbourne: Octopus Publishing.

Moss, R. (1983). Video the educational challenge. Beckenham, Kent: Croom Helm.

Palmer, P. \& Black, D. (1987). National Survey of Secondary Teachers Use of $A B C$ Schools Television programs. Sydney: ABC Research.

Palmer, P. (1986). The Lively Audience. Sydney: Allen \& Unwin.

Peach, B. (1992). This Day Tonight. Sydney: ABC Enterprises.

Perlgut, D. (1989). Future directions for ABC Television Adult Education. ABC TV Childrens and Education Department.

Perlgut, D. (1991). The ABC and adult literacy. Media Information Australia, 61, 98-104.

Ramsay, G. (1987a). Departmental rivalries: the News and Public Affairs Departments in the ABC. Paper presented to the Sociological Association of Australia and New Zealand Conference.

Ramsay, G. (1987b). ABC Education Television: An endangered species. Working paper No 2, School of Humanities and Applied Social Sciences, Nepean College of Advanced Education.

Ramsay, G. (1987c). Aboriginal music: the development of an education radio series. Paper presented to the Second Contemporary issues in Aboriginal Studies Conference, Sydney.

Ramsay, G. (1988a). The ABC's changing role as a provider of education television programs. Australian Journal of Educational Technology, 4(1), 31-45. http:/ / www.ascilite.org.au / ajet/ajet4 / ramsay.html 
Ramsay, G. (1988b). Passwords: A functional approach to teaching language by television. In J. Steele and J. G. Hedberg (eds), Designing for Learning in Industry and Education, 136-144. Proceedings of EdTech'88. Canberra: AJET Publications. http:/ / www.ascilite.org.au / asetarchives/confs/edtech88/ramsay.html

Ramsay, G. (1989a). Education Television and Video as communication. Paper presented to the Second International Experiential Learning Conference. Hawkesbury.

Ramsay, G. (1989b). Dramatising history in education television. Paper presented to the Fifth History and Film Conference. Sydney.

Ramsay, G. (1990a). The convergence of teaching and production in media centres. In J. G. Hedberg, J. Steele and M. Mooney (eds), Converging Technologies: Selected papers from EdTech'90, 135-140. Canberra: AJET Publications. http:/ / www.ascilite.org.au/ asetarchives/confs/ edtech90/ ramsay.html

Ramsay, G. (1990b). Literacy across different media: from diary to miniSeries. Australian Journal of Communication, 17(2), 37-47.

Ramsay, G. (1991). The Past, Present \& Future of Educational Television. In Healey, J. (ed), A Report on Educational Broadcasting in the '90s. Ryde: Department of School Education.

Rice, R. E. \& Atkin, C. (eds) (1989). Public Communication Campaigns. Newbury Park, Sage.

Steele, J. (ed) (1988). Ask the Workers... Evaluation. Australian Caption Centre: Sydney

Tracey, M. (1990). Wire and Lights. Australian National Broadcasters in the 1990s. Communications Law Centre: Sydney.

Widdowson, K. (1990). The Learning Network Experience. Media Information Australia, 58, 162-167.

Author: Grahame Ramsay is the Coordinator of the Media Production Specialisation in the BA (Applied Communication) at the University of Western Sydney, Nepean.

Please cite as: Ramsay, G. (1992). Adult education and school programs: The two co-funded ABC educational TV services. Australian Journal of Educational Technology, 8(1), 35-50.

http: / / www.ascilite.org.au/ajet/ajet8/ ramsay1.html 